\title{
The comprehensive therapeutic effects of rectal surgery are better in laparoscopy: a systematic review and meta-analysis
}

\author{
Jiabin Zheng ${ }^{1, *}$, Xingyu Feng ${ }^{1, *}$, Zifeng Yang ${ }^{1}$, Weixian Hu ${ }^{1,2}$, Yuwen Luo ${ }^{1,2}$, Yong Li ${ }^{1}$ \\ ${ }^{1}$ Department of General Surgery, Guangdong General Hospital and Guangdong Academy of Medical Sciences, Guangzhou, \\ 510080, China \\ ${ }^{2}$ Southern Medical University, Guangzhou, 510515, China \\ *These authors contributed equally to this work
}

Correspondence to: Yong Li, email: yuan821007@126.com

Keywords: laparoscopy, open, rectal cancer, meta-analysis

Received: September 28, $2016 \quad$ Accepted: December 20, 2016

Published: December 26, 2016

\section{ABSTRACT}

Background: Laparoscopic-assisted radical resection of rectal cancer was reported as advantageous compared to laparotomy resection. However, this finding remains controversial, especially given the two recent randomized controlled trials published on The Journal of the American Medical Association (JAMA).

Objective: To perform a meta-analysis that compares the short-term and longterm outcomes of laparoscopic and open surgery for rectal cancer.

Data source: To identify clinical trials comparing laparoscopic and open surgery for rectal cancer published by August 2016, we searched the PubMed, Cochrane Library, Springer Link and Clinicaltrials.gov databases by combining various key words. Data were extracted from every identified study to perform a meta-analysis using the Review Manager 5.3 software.

Results: A total of $\mathbf{4 3}$ articles from 38 studies with a total of 13408 patients were included. Although laparoscopic radical rectectomy increased operation time ( $M D=37.23,95 \%$ CI: 28.88 to $45.57, P<0.0001$ ), it can significantly decrease the blood loss (MD $=-143.13,95 \% \mathrm{CI}:-183.48$ to $-102.78, P<0.0001$ ), time to first bowel movement ( $M D=-0.97,95 \% \mathrm{CI}:-1.35$ to $-0.59, P<0.0001$ ), length of hospital stay (MD $=-2.40,95 \%$ CI: -3.10 to $-1.70, P<0.0001$ ), postoperative complications (OR $=0.78,95 \% \mathrm{CI}$ : 0.72 to $0.86, P<0.0001)$, mortality $(\mathrm{OR}=0.40$, 95\% CI: 0.28 to $0.57, P<0.0001$ ) and the CRM positive rate (OR $=0.64,95 \%$ CI: 0.55 to $0.75, P<0.0001$ ). No significant difference were noted between the groups regarding intraoperative complications, TME completeness and harvesting of lymph nodes. Regarding the long-term survival data, the laparoscopic group was not inferior to laparotomy. Some pooled data, such as 3-year DFS, 5-year OS and 5-year local recurrence were even superior for the laparoscopic group.

Conclusions: Given the definite benefits in short-term outcomes and trending benefits in long-term outcomes that were observed, we recommend laparoscopic surgery be used for rectal cancer resection.

\section{INTRODUCTION}

Rectal cancer is one of the most common malignant tumors. Surgical therapy plays an important role in the comprehensive treatment of rectal cancer, especially when the total mesorectal excision (TME) theory is applied to radical rectal resection, which can significantly improve the prognosis of patients with rectal cancer [1]. With the development of minimally invasive surgery, laparoscopicassisted radical rectectomy has been accepted by more and more surgeons. Many researches have shown its advantages on postoperative recovery and complications, while some have shown its disadvantages on operation time. The most controversial issues focus on pathology 
and long-term survival [2]. Therefore, some meta-analyses focused on either short-term or long-term indexes were previously carried out and have tried to solve these problems. Most of these meta-analyses show no significant differences between laparoscopy and open groups [3]. However, two randomized controlled trials (RCTs) published in Journal of American Medical Association (JAMA) were diametrically opposed to the results of previous clinical trials $[4,5]$. These two trials concluded that the non-inferiority of laparoscopic compared to open surgery was not established. Therefore, a systematic review and meta-analysis was undertaken to update these studies and evaluate both the short-term and long-term results of laparoscopic and open radical rectectomy.

\section{RESULTS}

\section{Studies included}

A total of 7655 citations from four databases met our search criteria up to August 2016. Review of the full-text articles revealed 43 articles that adequately matched the inclusion and exclusion criteria, which contained shortterm and long-term results from 38 different studies [4-46]. The studies that were included in this meta-analysis included thirteen RCTs and, twenty-five non-RCTs with a total number of 13408 patients who suffered from rectal cancer. The study screening and selection processes are presented in Figure 1. Quality assessment of the included articles and the characteristics of the included patients are presented in Table 1 .

\section{Surgical outcomes}

Operation time, blood loss and intraoperative complications are the most important outcomes for surgical procedure. Operation time was reported in 18 studies, including 4350 patients in the laparoscopic group and 6326 patients in the open group. The mean operation time ranged from 138 to $266 \mathrm{~min}$ in the laparoscopic group and from 127 to $240 \mathrm{~min}$ in the open group. Significantly longer operation times were noted in the laparoscopic group compared to the open group $(\mathrm{MD}=37.23,95 \% \mathrm{CI}: 28.88$ to $45.57, P<0.0001, \mathrm{I}^{2}=95 \%$ ) (Figure 2 ).

There were also 18 studies that reported operative blood loss, with a total number of 2289 patients in the laparoscopic group and 2069 patients in the open group. The mean blood loss ranged from 20 to $500 \mathrm{ml}$ and 92 to $1000 \mathrm{ml}$ for the laparoscopic and open groups, respectively. In this meta-analysis, a significant difference was noted between the laparoscopic and open groups. The blood loss in the laparoscopic group was obviously less than the open group (MD $=-143.13,95 \% \mathrm{CI}:-183.48$ to -102.78 , $P<0.0001, \mathrm{I}^{2}=97 \%$ ) (Figure 3 ) Given that the $\mathrm{I}^{2}$ was greater than $50 \%$, the random-effect model was used to calculate the pooled MD for operation time and blood loss.
Five studies reported intraoperative complications, including 1260 patients in the laparoscopic group and 763 patients in the open group. No significant differences were noted in intraoperative complications rate between these two groups $(\mathrm{OR}=0.90,95 \% \mathrm{CI}$ : 0.68 to $1.19, P=0.45$, $\mathrm{I}^{2}=47 \%$ ) (Figure 4$)$.

\section{Postoperative outcomes}

Postoperative outcomes refer to recovery speed and postoperative complications. We included the time to first bowel movement, length of hospital stay, total postoperative complications and postoperative mortality in our analysis. Thirteen studies reported the time to first bowel movement with a total number of 3769 patients for meta-analysis. As shown in Figure 5, the time to first bowel movement was shorter in the laparoscopic group than in the open group ( $\mathrm{MD}=-0.97,95 \% \mathrm{CI}:-1.35$ to $\left.-0.59, P<0.0001, \mathrm{I}^{2}=92 \%\right)$. Twenty-four studies reported the time of hospital stay with a total number of 10353 patients for meta-analysis. In this meta-analysis, a significant difference was noted between the laparoscopic group and open group $(\mathrm{MD}=-2.40,95 \% \mathrm{CI}$ : -3.10 to $-1.70, P<0.0001, \mathrm{I}^{2}=95 \%$ ) (Figure 6). Given that the $\mathrm{I}^{2}$ was greater than $50 \%$, the random-effect model was used to calculate the pooled MD for the time to first bowel movement and length of hospital stay.

There were 17 studies that reported postoperative complications and 16 studies that reported mortality, including 10214 and 9149 patients, respectively. The meta-analysis showed fewer postoperative complications $\left(\mathrm{OR}=0.78,95 \% \mathrm{CI}: 0.72\right.$ to $\left.0.86, P<0.0001, \mathrm{I}^{2}=31 \%\right)$ (Figure 7) and lower mortality in the laparoscopic group $\left(\mathrm{OR}=0.40,95 \% \mathrm{CI}: 0.28\right.$ to $\left.0.57, P<0.0001, \mathrm{I}^{2}=0 \%\right)$ (Figure 8).

\section{Pathology outcomes}

Pathology outcomes include lymph nodes harvesting, circumferential resection margin (CRM) positive rate and completeness of the TME. Most of the studies reported the number of harvested lymph nodes, with 10935 patients for meta-analysis. As Figure 8 shown, there was no significant difference between the laparoscopic and open groups in the number of harvested lymph nodes $\left(\mathrm{MD}=-0.37,95 \% \mathrm{CI}:-0.96\right.$ to $0.21, P=0.21, \mathrm{I}^{2}=79 \%$ ) (Figure 9). additionally, there was no significant difference in completeness of the TME between the two groups according to the meta-analysis of eight studies (OR $=1.09$, $95 \% \mathrm{CI}: 0.73$ to $1.64, P=0.66, \mathrm{I}^{2}=73 \%$ ) (Figure 10 ). Given that significant heterogeneity existed, the randomeffect model was applied to these two analyses.

Seventeen studies reported the CRM positive rate, including 3577 patients in the laparoscopic group and 5091 patients in the open group. Meta-analysis showed a significantly lower CRM positive rate in the laparoscopic 
Table 1: Study characteristics of included studies

\begin{tabular}{|c|c|c|c|c|c|c|c|}
\hline \multirow{2}{*}{ Study } & \multirow{2}{*}{ Study type } & \multirow{2}{*}{ Country } & \multirow{2}{*}{ Study period } & \multicolumn{2}{|c|}{ Number of patients } & \multirow{2}{*}{ Score } & \multirow{2}{*}{$\begin{array}{c}\text { Conversion } \\
\text { rate }\end{array}$} \\
\hline & & & & Laparoscopy & Open & & \\
\hline Zhou Z.G.2004 & RCT & China & Jun 2001 to Sep 2002 & 82 & 89 & MR & NR \\
\hline Pechlivanides G.2007 & RCT & Greece & NR & 34 & 39 & LR & $3 \%$ \\
\hline Braga M.2007 & RCT & Italy & NR & 83 & 85 & LR & $7.2 \%$ \\
\hline Ng S.S.2008 & RCT & Hong-Kong & Jul 1994 to Feb 2005 & 51 & 48 & LR & $9.8 \%$ \\
\hline Lujan J.2009 & RCT & \begin{tabular}{|l} 
Spain \\
\end{tabular} & Jan 2002 to Feb 2007 & 101 & 103 & LR & $7.9 \%$ \\
\hline Liang X.2011 & RCT & China & May 2004 to Apr 2008 & 169 & 174 & MR & $0.6 \%$ \\
\hline Gong J.2012 & $\mathrm{RCT}$ & China & Sep 2008 to Jul 2011 & 67 & 71 & MR & $2.99 \%$ \\
\hline CLASICC 2013 & RCT & UK & Jul 1996 to Jul 2002 & 253 & 128 & LR & $32.4 \%$ \\
\hline COREAN 2014 & RCT & Korea & Apr 2006 to Aug 2009 & 170 & 170 & LR & $1.2 \%$ \\
\hline Ng S.S.2014 & RCT & Hong-Kong & Aug 2001 to Aug 2007 & 40 & 40 & LR & $7.5 \%$ \\
\hline COLOR II 2015 & RCT & Europe & Jan 2004 to May 2010 & 699 & 345 & LR & $17 \%$ \\
\hline ALaKa 2015 & RCT & Australasia & Mar 2010 to Nov 2014 & 238 & 237 & LR & $9 \%$ \\
\hline Z6051 2015 & RCT & US \& Canada & Oct 2008 to Sep 2013 & 240 & 222 & LR & $11 \%$ \\
\hline Leung K.L.2000 & Non-RCT & Hong-Kong & Jan 1993 to Jan 1996 & 25 & 34 & 9 & $8.0 \%$ \\
\hline Anthuber M.2002 & Non-RCT & Germany & Jan 1996 to Mar 2003 & 101 & 334 & 9 & 0 \\
\hline Feliciotti F.2003 & Non-RCT & \begin{tabular}{|l} 
Italy \\
\end{tabular} & May 1992 to Apr 2002 & 52 & 34 & 9 & $12.3 \%$ \\
\hline Wu W.X.2004 & Non-RCT & \begin{tabular}{|l} 
China \\
\end{tabular} & Apr 2002 to May 2003 & 18 & 18 & 8 & 0 \\
\hline Breukink S.O.2005 & Non-RCT & \begin{tabular}{|l} 
Netherlands \\
\end{tabular} & Apr 1996 to Mar 2003 & 41 & 41 & 8 & $9.8 \%$ \\
\hline Morino M.2005 & Non-RCT & Italy & Apr 1994 to Apr 2002 & 98 & 93 & 9 & $18.4 \%$ \\
\hline Law W.L.2006 & Non-RCT & \begin{tabular}{|l} 
Hong-Kong \\
\end{tabular} & Jun 2000 to Dec 2004 & 98 & 167 & 8 & $12.2 \%$ \\
\hline Lelong B. 2007 & Non-RCT & France & Jan 1998 to Oct 2004 & 104 & 68 & 8 & $14.4 \%$ \\
\hline Veenhof A.A.2007 & Non-RCT & \begin{tabular}{|l} 
Netherlands \\
\end{tabular} & Feb 1999 to Nov 2005 & 50 & 50 & 9 & $8.0 \%$ \\
\hline Ströhlein M.A.2008 & Non-RCT & \begin{tabular}{|l} 
Germany \\
\end{tabular} & 1998 to 2005 & 114 & 275 & 9 & $21.9 \%$ \\
\hline González Q.H.2009 & Non-RCT & Mexico & Nov 2005 to Nov 2007 & 28 & 28 & 8 & 0 \\
\hline Gouvas N.2009 & Non-RCT & Greece & Jan 1998 to Mar 2007 & 45 & 43 & 8 & $9 \%$ \\
\hline Khaikin M.2009 & Non-RCT & America & Nov 2004 to Jul 2006 & 32 & 50 & 9 & $12.5 \%$ \\
\hline Koulas S.G.2009 & Non-RCT & Greece & Oct 1998 to Dec 2006 & 57 & 60 & 7 & $7.0 \%$ \\
\hline Laurent C.2009 & Non-RCT & France & $1994-2006$ & 238 & 233 & 9 & $15.1 \%$ \\
\hline Baik S.H.2011 & Non-RCT & Korea & Sep 2001 to Sep 2005 & 54 & 108 & 9 & $11.1 \%$ \\
\hline McKay G.D.2011 & Non-RCT & Australia & Jan 2001 to Dec 2008 & 157 & 388 & 8 & $8.3 \%$ \\
\hline Gunka I.2012 & Non-RCT & Czech & Jan 2001 to Dec 2006 & 75 & 70 & 8 & $5.9 \%$ \\
\hline Jefferies M.T.2012 & Non-RCT & \begin{tabular}{|l|} 
UK \\
\end{tabular} & Feb 2007 to Jun 2010 & 16 & 25 & 8 & $12.5 \%$ \\
\hline Kellokumpu I.H.2012 & Non-RCT & Finland & 1999 to 2006 & 100 & 91 & 9 & $22 \%$ \\
\hline Seshadri R.A.2012 & Non-RCT & India & Jan 2004 to Jan 2010 & 72 & 72 & 9 & $4.2 \%$ \\
\hline Lujan J.2013 & Non-RCT & Spain & 2006 to Jul 2013 & 1387 & 3018 & 9 & $17.4 \%$ \\
\hline Cho M.S.2015 & Non-RCT & Korea & Jan 2003 to Jun 2008 & 211 & 422 & 9 & $3 \%$ \\
\hline Kim J.H.2015 & Non-RCT & Korea & Jan 2002 to Dec 2011 & 131 & 176 & 7 & NR \\
\hline
\end{tabular}

Abbreviations: RCT: randomized controlled trial; LR: low risk; MR: moderate risk; NR: no reported.

group $(\mathrm{OR}=0.64,95 \% \mathrm{CI}: 0.55$ to $0.75, P<0.0001$, $\mathrm{I}^{2}=22 \%$ ) (Figure 11).

\section{Long-term survival data}

Ten studies reported the disease-free survival (DFS), 4 of which reported the 3-year DFS while the others reported the 5-year DFS. There was no significant difference between the laparoscopic and open group in 5-year DFS $(\mathrm{OR}=1.28,95 \% \mathrm{CI}: 0.97$ to $1.69, P=0.08$, $\mathrm{I}^{2}=0 \%$ ) (Figure 12), whereas the laparoscopic group showed a significantly higher 3-year DFS compared to the open group $(\mathrm{OR}=1.35,95 \% \mathrm{CI}: 1.07$ to $1.70, P=0.01$, $\left.I^{2}=16 \%\right)$ (Figure 13).

Twelve studies reported the overall survival (OS), 5 of which reported the 3-year OS while the others reported the 5-year OS. There was no significant difference between the laparoscopic and open groups in 3-year OS 


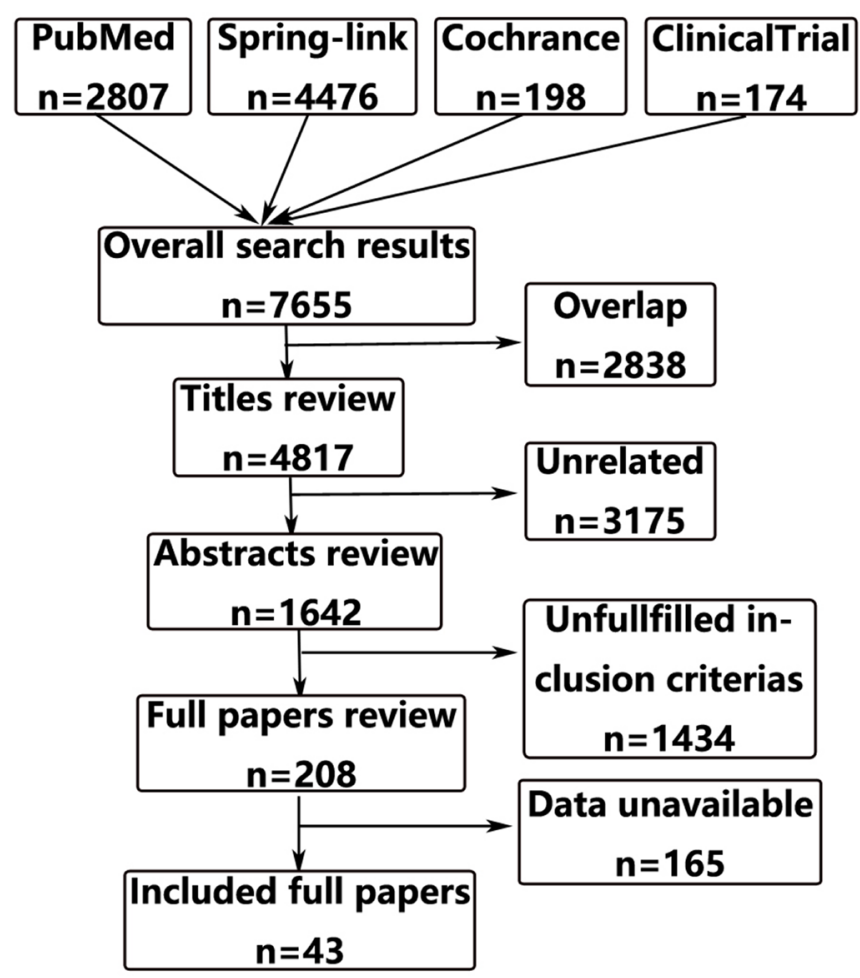

Figure 1: Flow diagram of articles included and excluded.

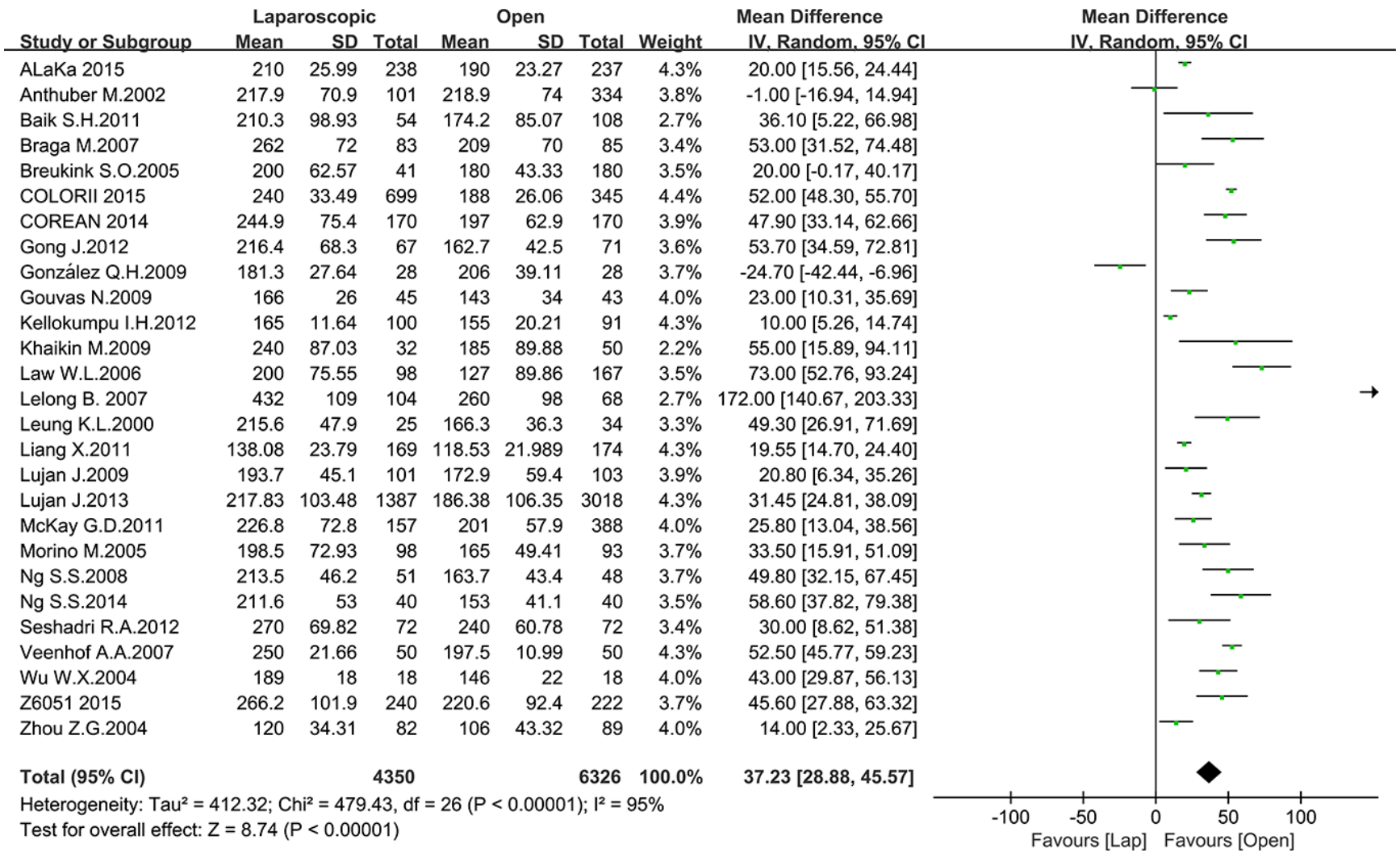

Figure 2: Pooled MD for operation time of including studies. 


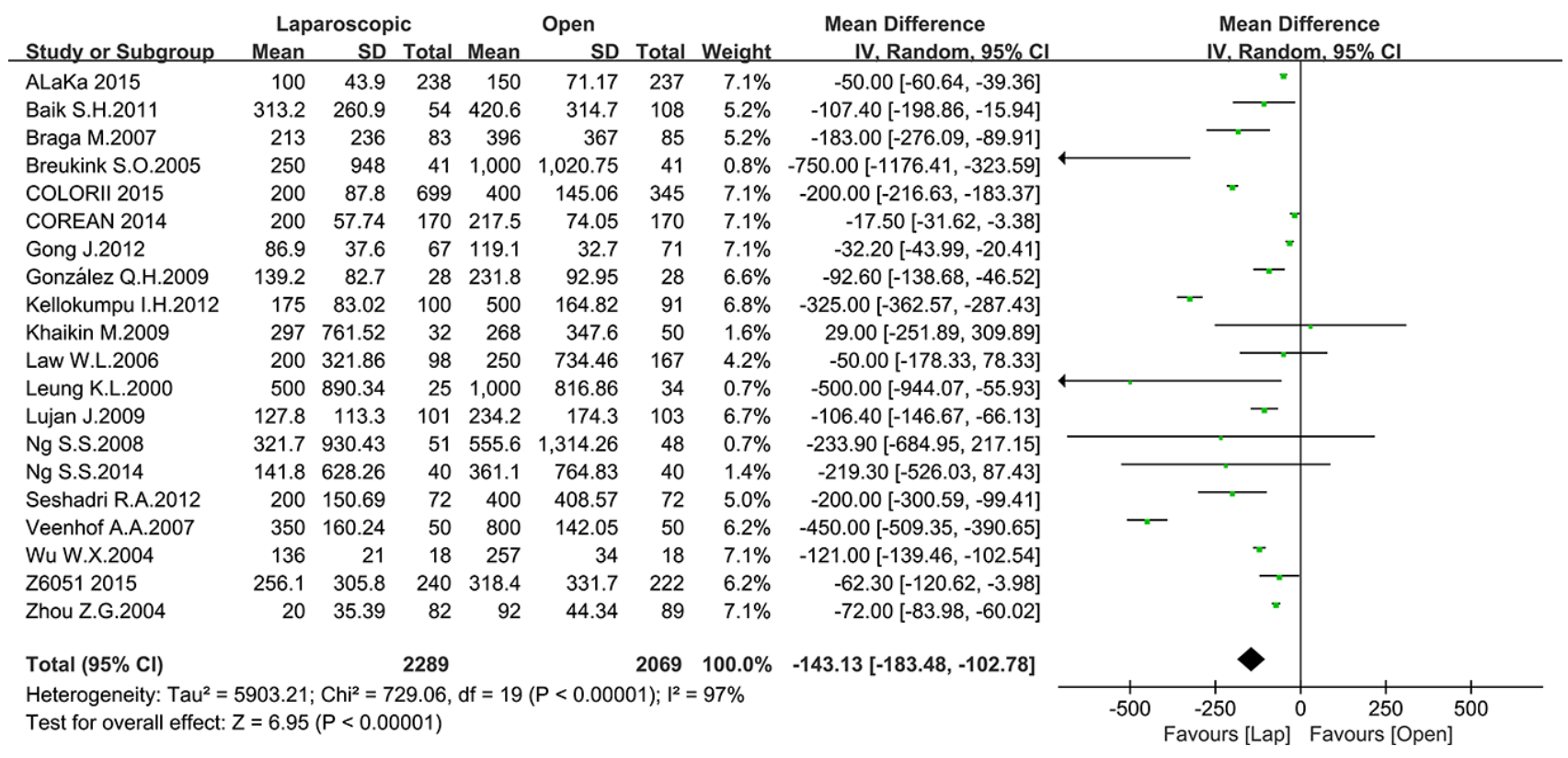

Figure 3: Pooled MD for blood loss of including studies.

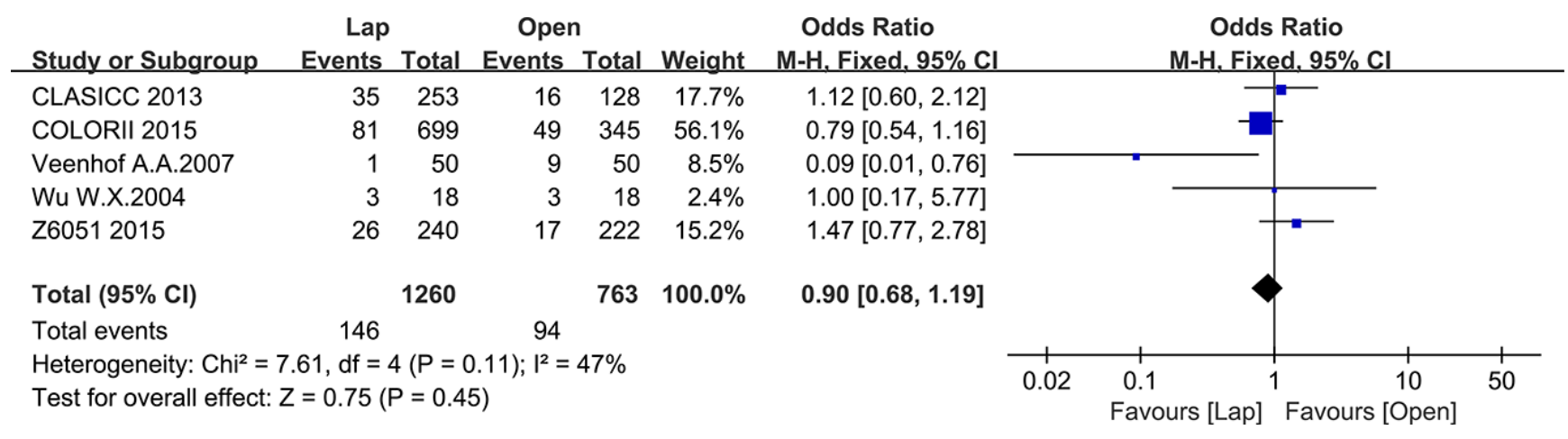

Figure 4: Pooled OR for intraoperative complications of including studies.

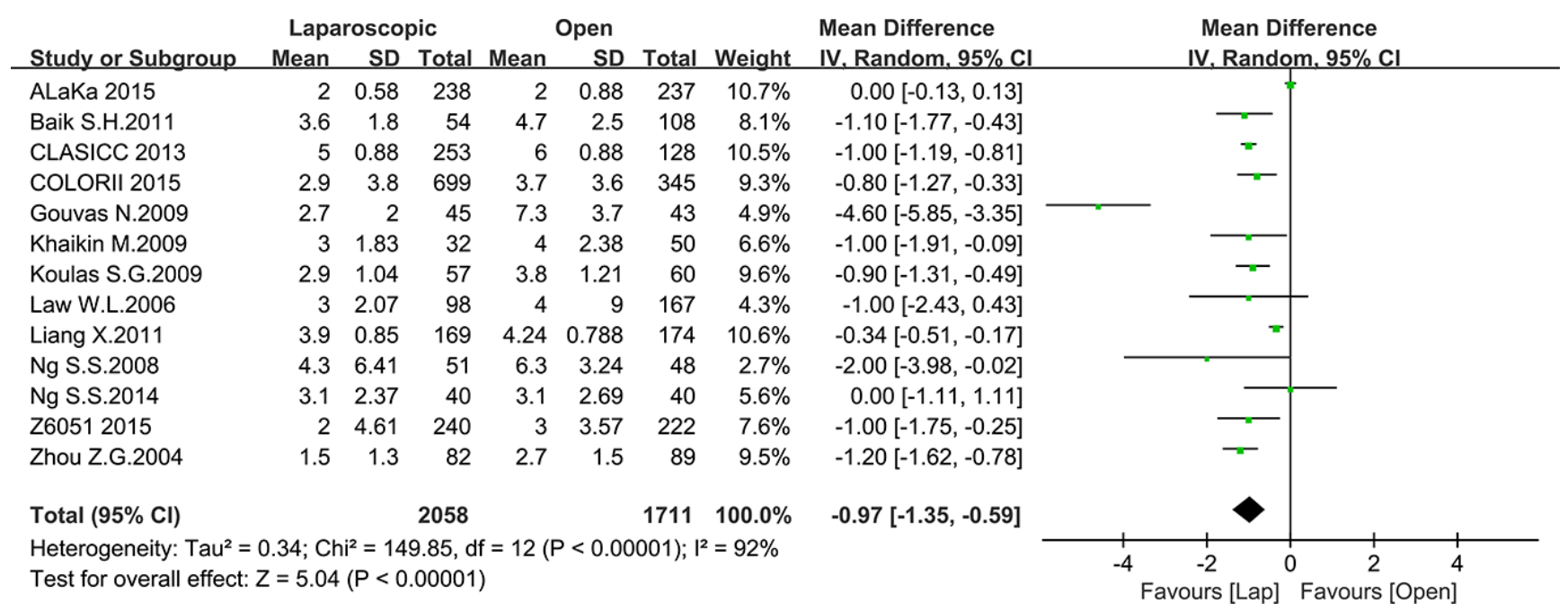

Figure 5: Pooled MD for first bowel movement of including studies. 
$\left(\mathrm{OR}=1.29,95 \% \mathrm{CI}: 0.71\right.$ to $\left.2.33, P=0.40, \mathrm{I}^{2}=68 \%\right)$ (Figure 14), whereas the laparoscopic group showed a significant higher 5-year OS compared to the open group $\left(\mathrm{OR}=1.31,95 \% \mathrm{CI}: 1.01\right.$ to $\left.1.68, P=0.04, \mathrm{I}^{2}=31 \%\right)$ (Figure 15).
Seven studies reported the 3-year local recurrence (LR) and nine studies reported the 5-year LR. There was no significant difference in the 3-year LR between the two groups $\left(\mathrm{OR}=0.85,95 \% \mathrm{CI}: 0.59\right.$ to $\left.1.23, P=0.39, \mathrm{I}^{2}=0 \%\right)$ (Figure 16), while the laparoscopic group showed a lower

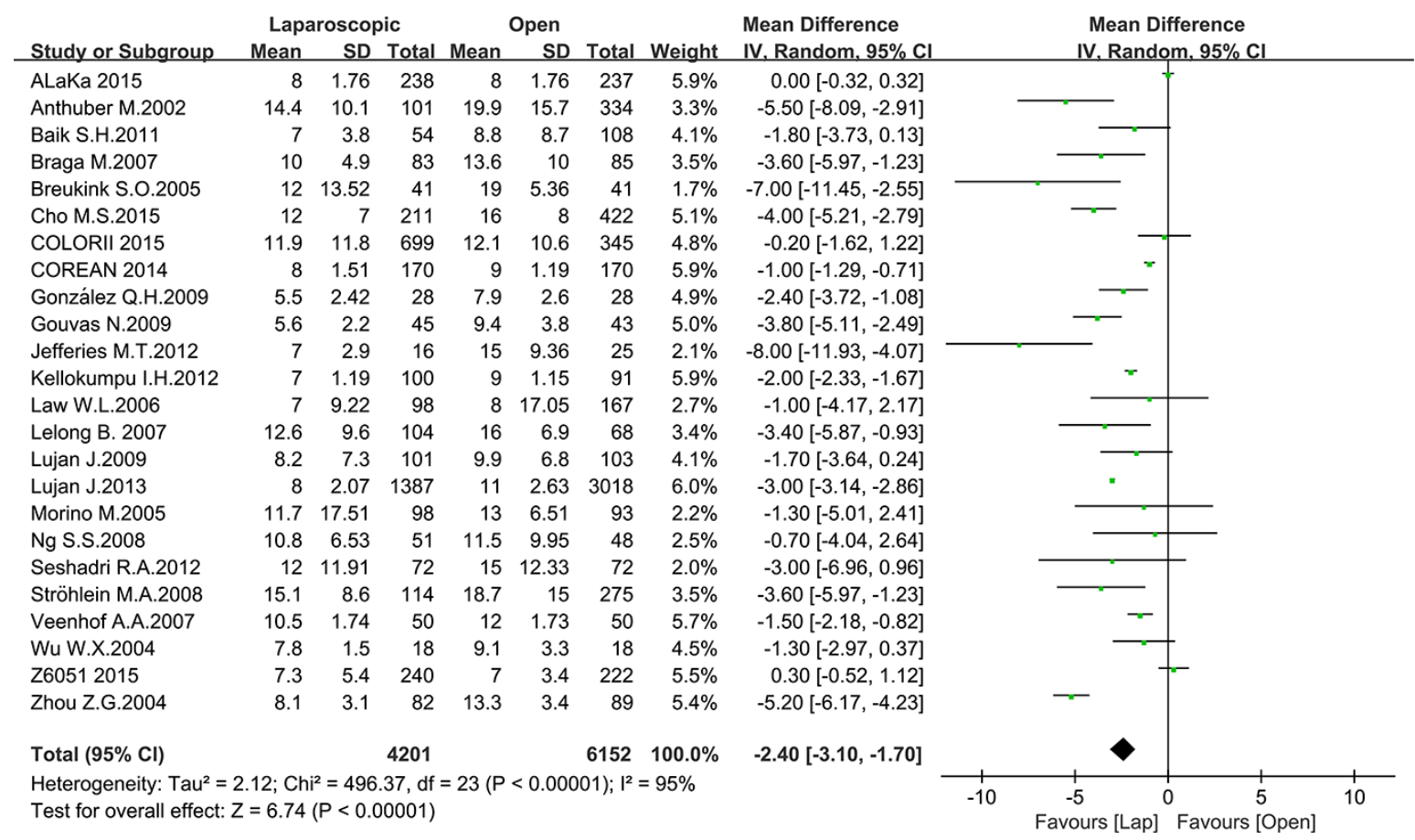

Figure 6: Pooled MD for length of hospital stay of including studies.

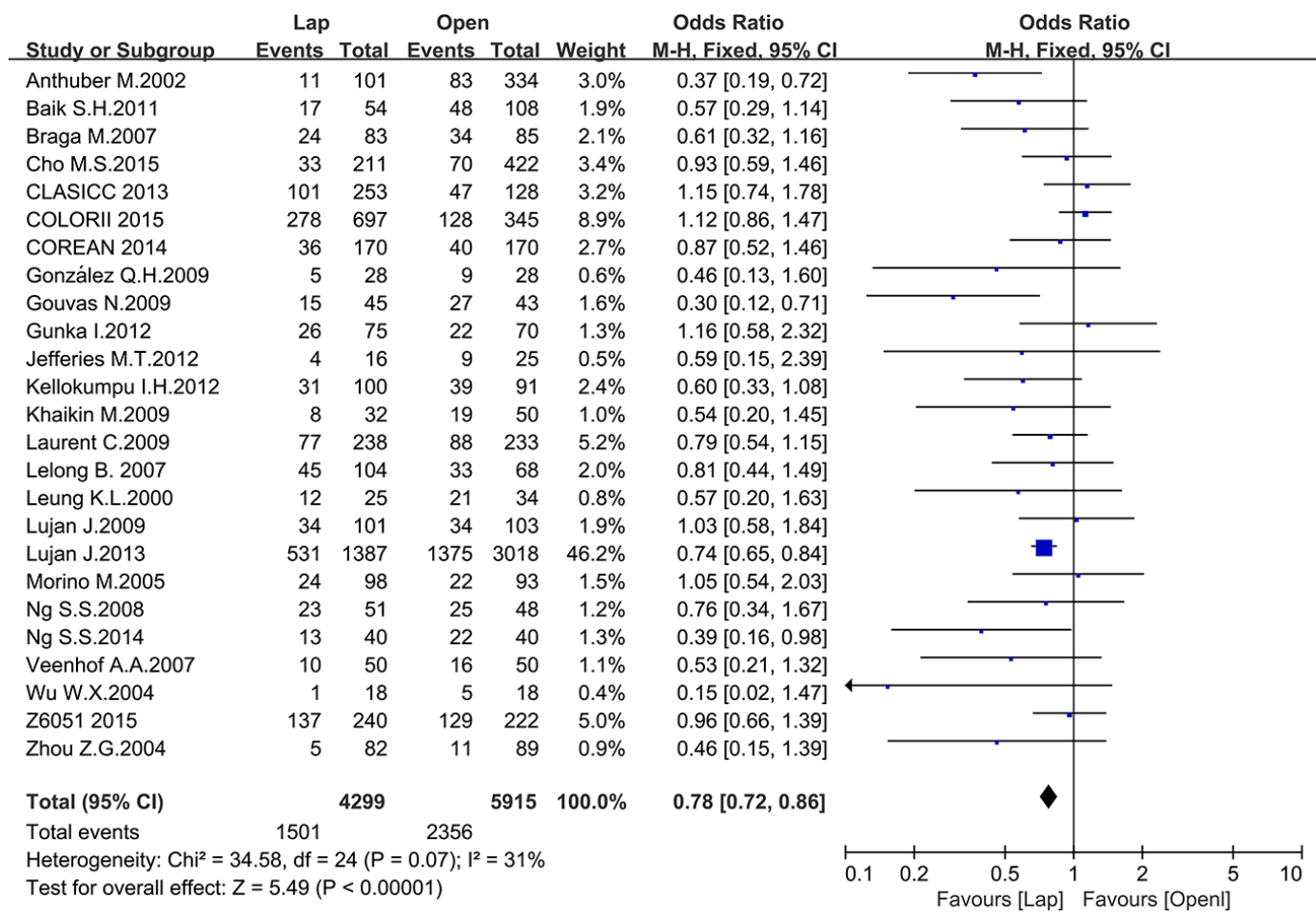

Figure 7: Pooled OR for postoperative complications of including studies. 


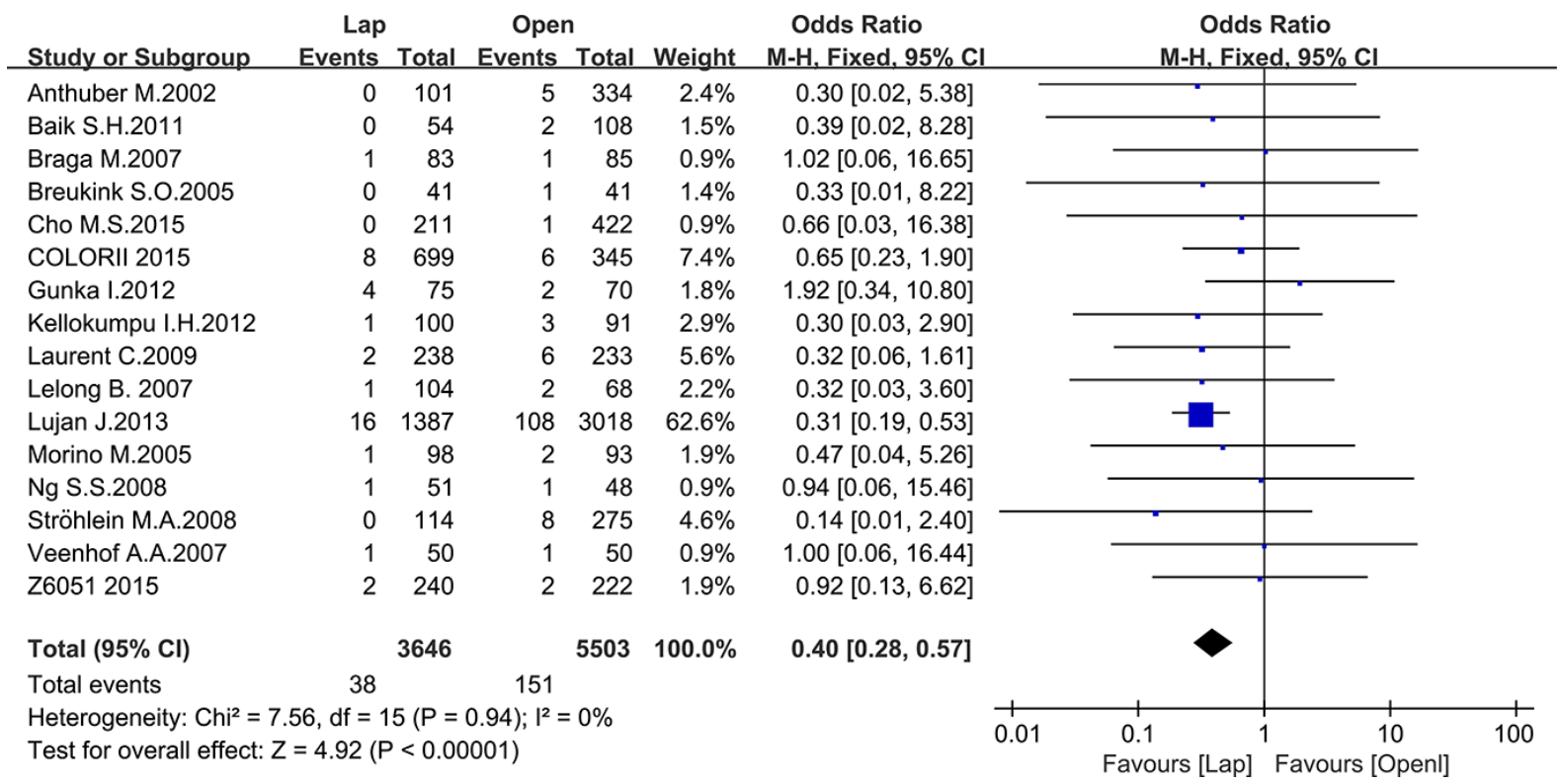

Figure 8: Pooled OR for postoperative mortality of including studies.

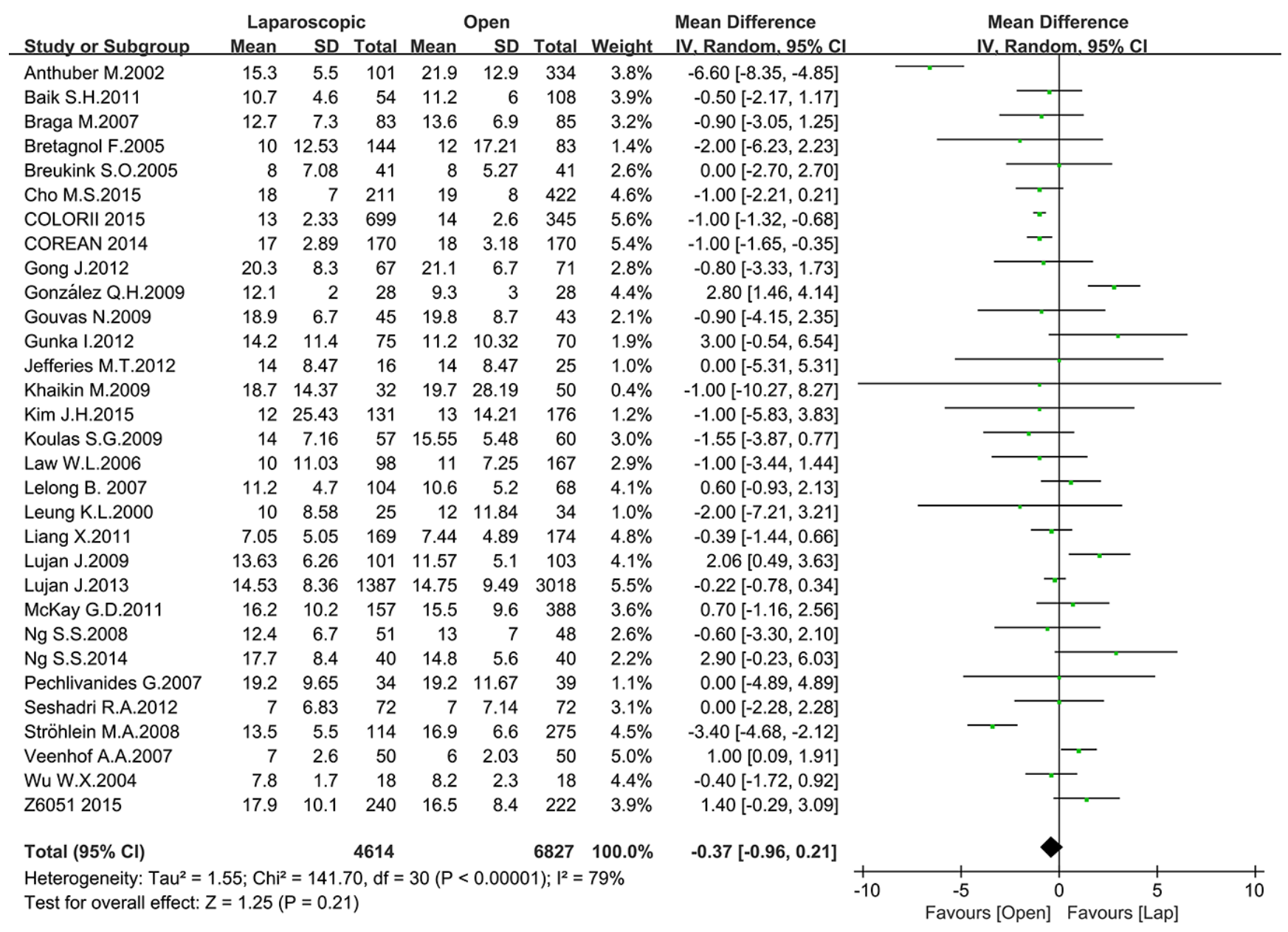

Figure 9: Pooled MD for number of harvested lymph nodes of including studies. 
5-year LR (OR $=0.57,95 \%$ CI: 0.38 to $0.87, P=0.009$, $\mathrm{I}^{2}=0 \%$ ) (Figure 17).

\section{DISCUSSION}

Laparoscopic-assisted radical rectectomy has been widely applied in clinical practice since it was first reported. However, the efficacy and safety of this procedure are still controversial. Many clinical trials and meta-analyses have been designed to prove its feasibility. When everything seemed to reach an agreement that laparoscopic-assisted radical rectectomy is feasible, two randomized clinical trials published in JAMA went against this opinion $[4,5]$. Therefore, we conducted this meta-analysis to pool the latest research data and probe these discrepancies. Because too many outcomes were reported, we choose some of the most important outcomes for analysis and divided them into four types, including surgical outcomes, postoperative outcomes, pathology outcomes and long-term survival data.

We choose three surgical and postoperative outcomes for meta-analysis, which are the important indicators of surgical safety. Given the irregularity of laparoscopic skill levels, the observed heterogeneity in surgical outcomes was expected. We had to analyze the data using a random-effect model. As was shown in the meta-analysis, the operation time was significantly longer in laparoscopic group. After all, laparoscopic radical rectectomy is a relatively new surgical approach in comparison to open surgery. Most surgeons lack proficiency in laparoscopic surgery. And this is why many people still have doubts about laparoscopic surgery. As practice and proficiency increase, the operation time will undoubtedly decrease.

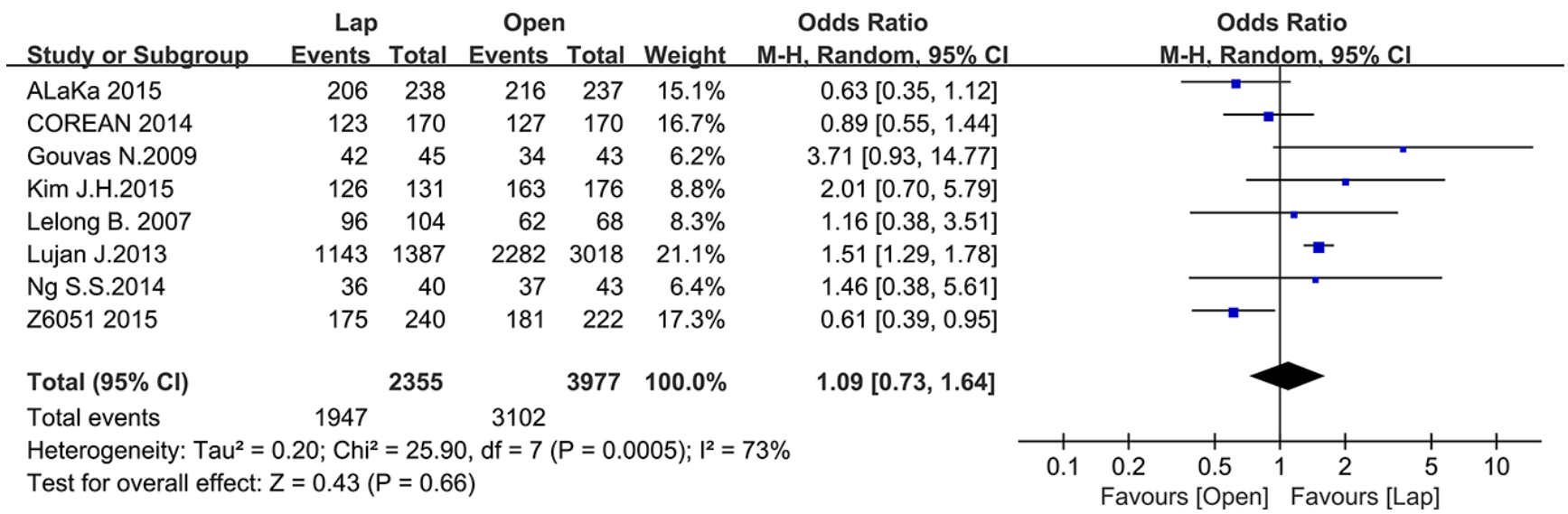

Figure 10: Pooled OR for TME completeness of including studies.

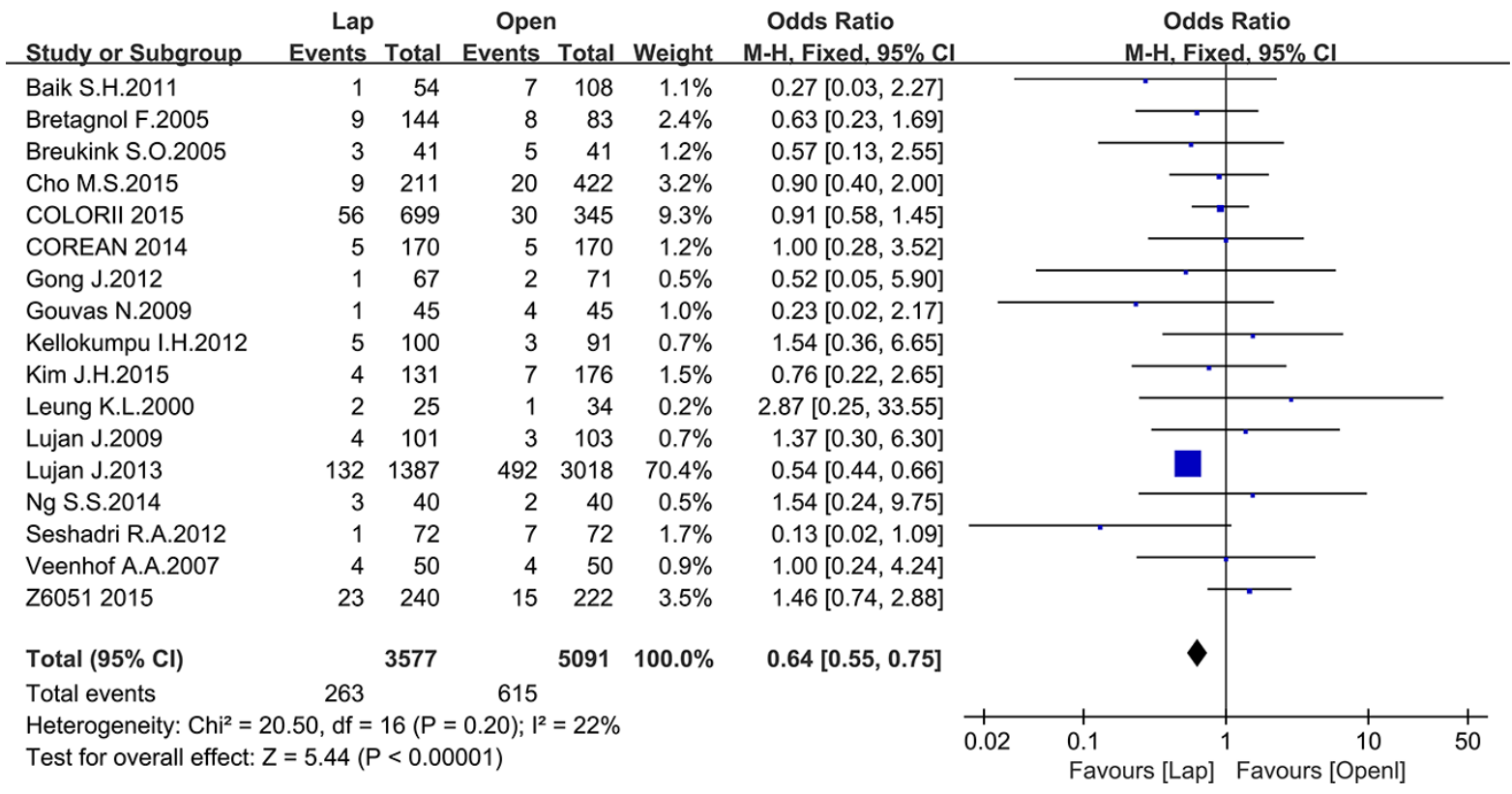

Figure 11: Pooled OR for CMR positive rate of including studies. 
On the other hand, laparoscopy has its own advantages. It can magnify the operative region and help to identify and protect the important structures, which makes the operation more precise. What is more, it decreases the disruption of normal tissue. As a result, the blood loss, complication and mortality rates were lower, and the time to first bowel movement and length of hospital stay were shorter, which indicates less over tissue damage and faster recover.

Pathology outcomes were used as the main outcomes in the latest two JAMA trials. The quality of the specimen closely relates to the degree of radical resection. TME completeness, CRM positive rate and number of harvested lymph nodes were the most important indicators. In our meta-analysis, the CRM positive rate was significantly lower in the laparoscopic group, whereas no significant differences in harvested lymph nodes numbers or TME completeness was seen. In our opinion, however, pathology outcomes should be treated as important indicators of surgical quality but not as the endpoint of cancer therapy. The main evaluation criteria of surgical approaches should be based on patients' long-term survival benefits, especially the OS and DFS. For example, the Dutch trial, with a 15-year follow-up period, meets this criteria quite well [47]. As demonstrated in the COREAN trial [46] and COLOR II trial [11], some short-term outcomes, including

\begin{tabular}{|c|c|c|c|c|c|c|c|c|}
\hline Study or Subgroup & $\begin{array}{r}\text { Lap } \\
\text { Events }\end{array}$ & Total & $\begin{array}{c}\text { Oper } \\
\text { Events }\end{array}$ & Total & Weight & $\begin{array}{c}\text { Odds Ratio } \\
\text { M-H, Fixed, } 95 \% \mathrm{Cl}\end{array}$ & $\begin{array}{r}\text { Odds } \\
\text { M-H, Fix }\end{array}$ & $\begin{array}{l}\text { S Ratio } \\
\text { ed, } 95 \% \mathrm{Cl}\end{array}$ \\
\hline Baik S.H.2011 & 44 & 54 & 82 & 108 & $11.4 \%$ & $1.40[0.62,3.16]$ & & \\
\hline Laurent C.2009 & 195 & 238 & 184 & 233 & $37.8 \%$ & $1.21[0.77,1.91]$ & & \\
\hline Lujan J.2009 & 86 & 101 & 83 & 103 & $13.7 \%$ & $1.38[0.66,2.88]$ & & \\
\hline Morino M.2005 & 64 & 98 & 55 & 93 & $22.0 \%$ & $1.30[0.72,2.34]$ & & \\
\hline Ng S.S.2008 & 40 & 51 & 35 & 48 & $8.8 \%$ & $1.35[0.54,3.40]$ & & \\
\hline Ng S.S.2014 & 33 & 40 & 32 & 40 & $6.3 \%$ & $1.18[0.38,3.63]$ & & \\
\hline Total $(95 \% \mathrm{Cl})$ & & 582 & & 625 & $100.0 \%$ & $1.28[0.97,1.69]$ & & \\
\hline Total events & 462 & & 471 & & & & & \\
\hline \multicolumn{7}{|c|}{$\begin{array}{l}\text { Heterogeneity: } \mathrm{Chi}^{2}=0.18, \mathrm{df}=5(P=1.00) ; I^{2}=0 \% \\
\text { Test for overall effect: } Z=1.77(P=0.08)\end{array}$} & $\begin{array}{cc}0.5 & 0.7 \\
\text { Favours } & \text { [Open] }\end{array}$ & $\begin{array}{cc}1.5 & 2 \\
\text { Favours [Lap] }\end{array}$ \\
\hline
\end{tabular}

Figure 12: Pooled OR for 5-year DFS of including studies.

\begin{tabular}{|c|c|c|c|c|c|c|c|c|c|c|}
\hline Study or Subgroup & $\begin{array}{r}\text { Lap } \\
\text { Events }\end{array}$ & Total & $\begin{array}{r}\text { Ope } \\
\text { Events }\end{array}$ & & Weight & $\begin{array}{c}\text { Odds Ratio } \\
\text { M-H, Fixed, } 95 \% \mathrm{Cl}\end{array}$ & & $\begin{array}{r}\mathrm{O} \\
\mathrm{M}-\mathrm{H},\end{array}$ & $\begin{array}{l}\text { ds Ratio } \\
\text { xed. } 95 \% \mathrm{Cl}\end{array}$ & \\
\hline COLORII 2015 & 523 & 699 & 244 & 345 & $67.1 \%$ & $1.23[0.92,1.64]$ & & & & \\
\hline COREAN 2014 & 135 & 170 & 123 & 170 & $20.6 \%$ & $1.47[0.89,2.43]$ & & & & \\
\hline Feliciotti F.2003 & 33 & 52 & 21 & 34 & $7.6 \%$ & $1.08[0.44,2.63]$ & & & & \\
\hline Veenhof A.A.2007 & 40 & 50 & 29 & 50 & $4.7 \%$ & $2.90[1.19,7.07]$ & & & & \\
\hline Total $(95 \% \mathrm{Cl})$ & & 971 & & 599 & $100.0 \%$ & $1.35[1.07,1.70]$ & & & & \\
\hline Total events & 731 & & 417 & & & & & & & \\
\hline \multicolumn{7}{|c|}{ Heterogeneity: $\mathrm{Chi}^{2}=3.58, \mathrm{df}=3(\mathrm{P}=0.31) ; \mathrm{I}^{2}=16 \%$} & 0.2 & 0.5 & 2 & 5 \\
\hline
\end{tabular}

Figure 13: Pooled OR for 3-year DFS of including studies.

\begin{tabular}{|c|c|c|c|c|c|c|c|c|c|c|}
\hline Study or Subgroup & $\begin{array}{l}\text { Lap } \\
\text { Events }\end{array}$ & Total & $\begin{array}{l}\text { Oper } \\
\text { Events }\end{array}$ & Total & Weight & $\begin{array}{l}\text { Odds Ratio } \\
\text { M-H, Random, } 95 \% \mathrm{Cl}\end{array}$ & & $\begin{array}{r}\text { Odds } \\
\text { M-H, Rando }\end{array}$ & $\begin{array}{l}\text { Ratio } \\
\text { dom. } 95 \% \mathrm{Cl}\end{array}$ & \\
\hline COLORII 2015 & 606 & 699 & 288 & 345 & $31.2 \%$ & $1.29[0.90,1.85]$ & & & & \\
\hline COREAN 2014 & 156 & 170 & 154 & 170 & $22.5 \%$ & $1.16[0.55,2.45]$ & & & & \\
\hline Jefferies M.T.2012 & 12 & 16 & 16 & 25 & $12.0 \%$ & $1.69[0.42,6.81]$ & & & & \\
\hline Liang X.2011 & 128 & 169 & 144 & 174 & $27.6 \%$ & $0.65[0.38,1.10]$ & & 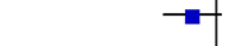 & & \\
\hline Veenhof A.A.2007 & 49 & 50 & 36 & 50 & $6.7 \%$ & $19.06[2.40,151.60]$ & & & & \\
\hline Total $(95 \% \mathrm{Cl})$ & & 1104 & & 764 & $100.0 \%$ & $1.29[0.71,2.33]$ & & & & \\
\hline Total events & 951 & & 638 & & & & & & & \\
\hline \multicolumn{7}{|c|}{$\begin{array}{l}\text { Heterogeneity: } \mathrm{Tau}^{2}=0.26 ; \mathrm{Chi}^{2}=12.37, \mathrm{df}=4(P=0.01) ; \mathrm{I}^{2}=68 \% \\
\text { Test for overall effect: } Z=0.83(P=0.40)\end{array}$} & 0.01 & $\begin{array}{cc}0.1 & 1 \\
\text { Favours [Open] }\end{array}$ & $\begin{array}{lr}1 & 10 \\
\text { Favours [La }\end{array}$ & 100 \\
\hline
\end{tabular}

Figure 14: Pooled OR for 3-year OS of including studies. 
pathology outcomes, in the open group were superior to those in the laparoscopic group, but all these advantages did not transform into a survival benefit.

In this meta-analysis, the pooled long-term survival data demonstrated that laparoscopic surgery was not inferior to laparotomy. The 3-year DFS, 5-year OS and 5-year local recurrence rates were significantly superior in patients who received laparoscopic resection. This result is reasonable given the advantages mentioned above. However, some survival data still did not reach statistical significance in this meta-analysis. As far as we are concerned, the laparoscopic radical rectectomy may

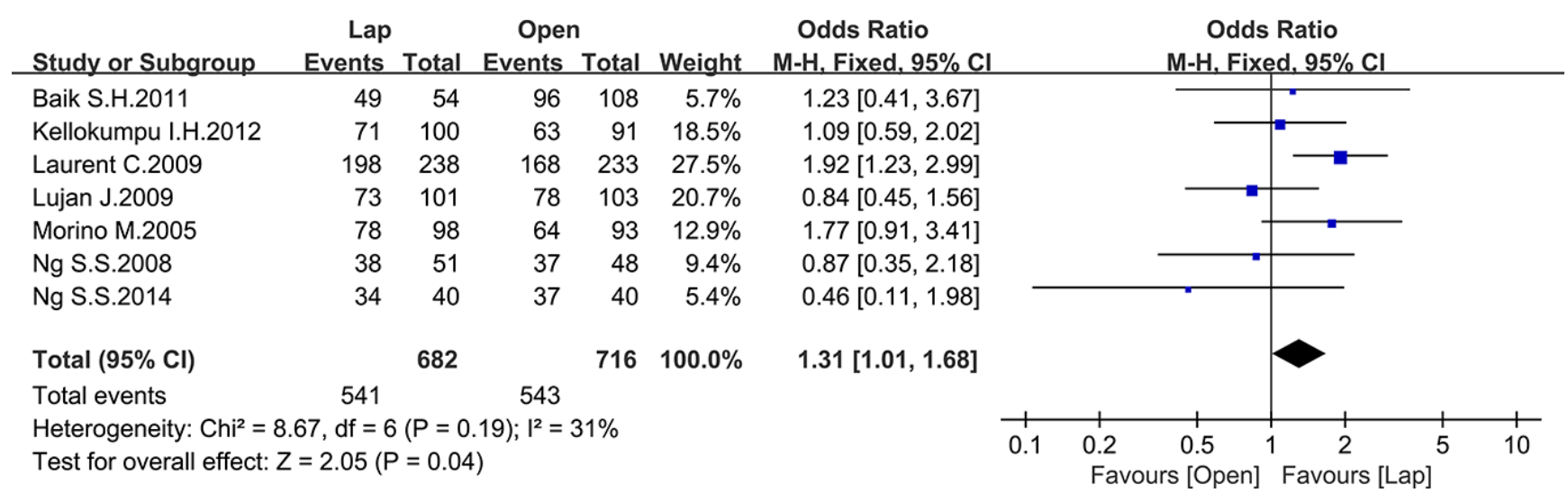

Figure 15: Pooled OR for 5-year OS of including studies.

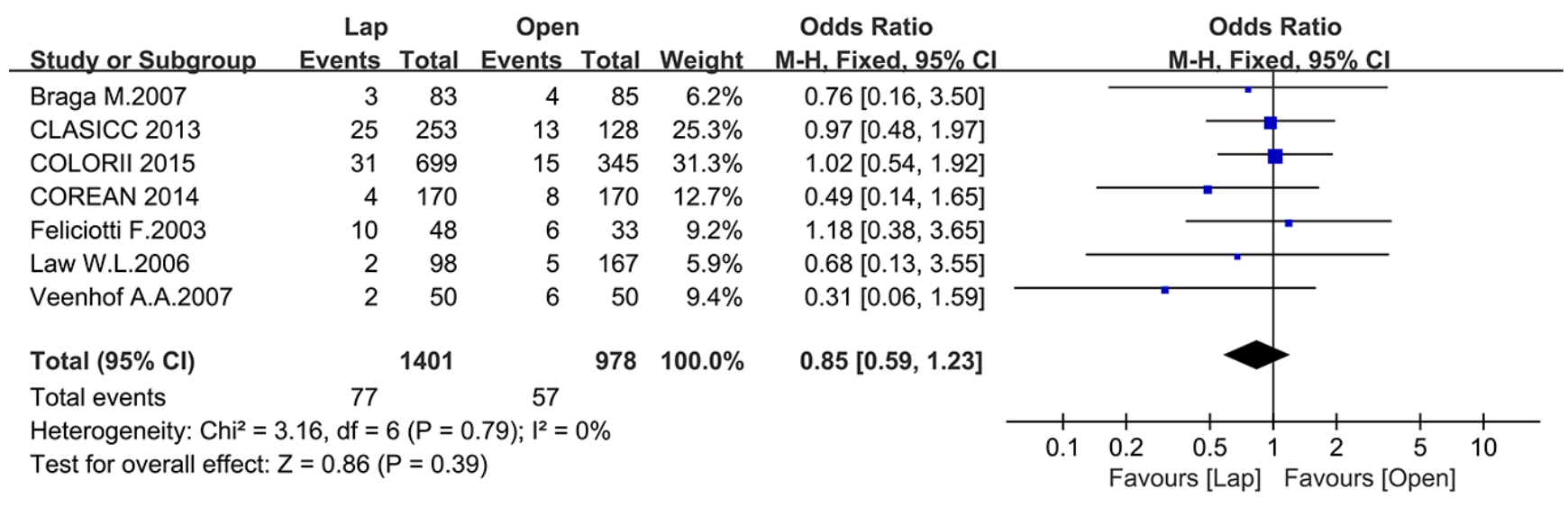

Figure 16: Pooled OR for 3-year local recurrence rate of including studies.

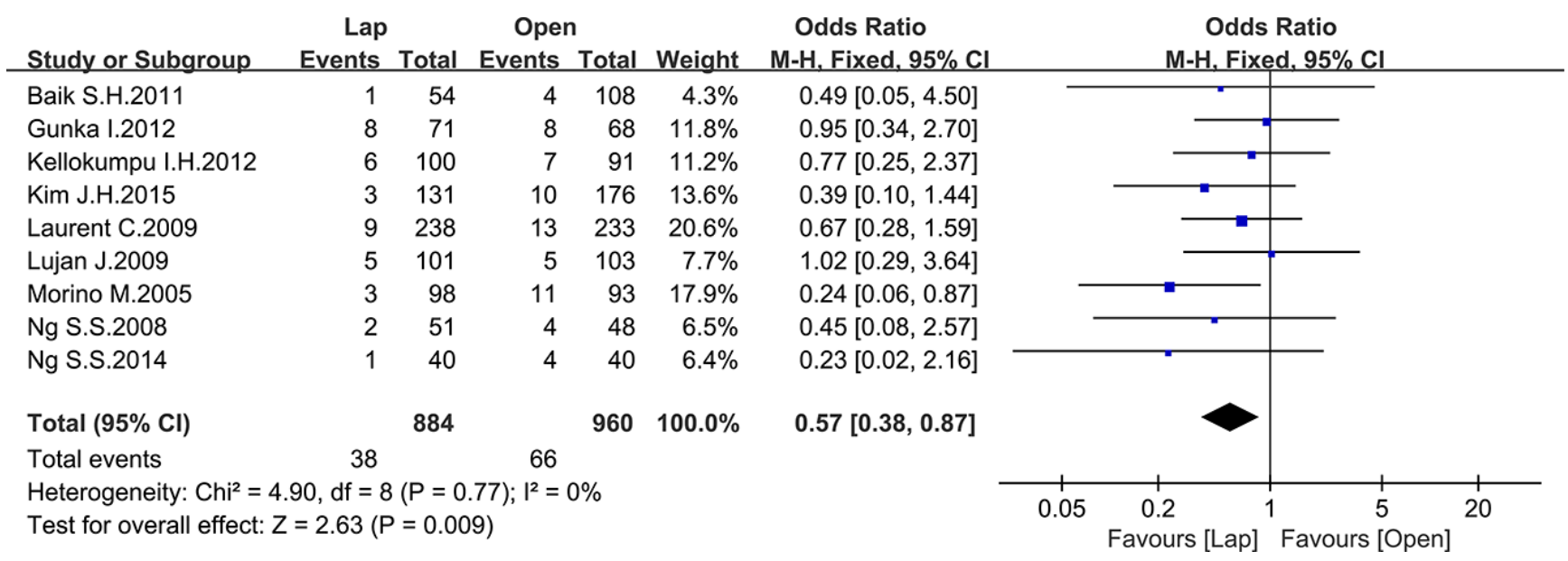

Figure 17: Pooled OR for 5-year local recurrence rate of including studies. 
not show its advantage in long-term survival given our collective history of unskilled laparoscopic technique. The prognosis of patients with rectal cancer will significantly improve as laparoscopy technique becomes more mature. We are looking forward to the survival data of the latest trials and even more reasonably designed new trials.

In conclusion, given the definite benefits of shortterm outcomes and trending benefits of long-term outcomes that were observed, we recommend laparoscopic surgery be used in rectal cancer resection.

\section{MATERIALS AND METHODS}

\section{Study selection}

A systematical search of all relevant literature published until August 2016 was performed using the following 4 online databases: PubMed, Cochrane Library, Springer Link and Clinicaltrials.gov. The key search terms used in various combinations included "rectal cancer," "rectal neoplasm," and "laparoscopy," "laparoscopic," "minimally invasive". All searches and literature selections were independently conducted by two investigators (Zheng and Feng).

\section{Inclusion and exclusion criteria}

All clinical trials that compared laparoscopic surgery and open surgery were included. All literature that failed to fulfill the following criteria were excluded: (1) the patients presented with rectal cancer, (2) the study compared patients who underwent laparoscopy to patients who underwent open surgery (3) the study was written in English. All included studies were independently assessed by two authors (Zheng and Feng).

\section{Quality assessment}

Study quality was assessed independently by two authors (Zheng and Feng). All of the RCTs were assessed by the Cochrane Collaboration's tool, whereas the nonRCT studies were assessed by the Newcastle-Ottawa Scale (NOS). If controversy existed between the two independent evaluations, all of the authors participated in a discussion to resolve the issue. A score above 6 for non-RCT studies indicated high quality, otherwise, a lower score indicated poor quality.

\section{Data extraction}

Data form shortlisted articles were extracted independently by the two authors (Zheng and Feng) and entered into a pre-designed form after reaching a consensus. The main data reported included study characteristics and outcomes. Study characteristics, including the time, country, study type, number of patients, treatment, outcomes and quality score, are presented in Table 1. The study outcomes included operation time, blood loss, harvesting of lymph nodes, recovery time, hospital stay duration, permanent stomas rate, postoperative complications and postoperative death, et al.

\section{Statistical analysis}

Review Manager (RevMan) v5.3 (Cochrane Library) software was used to perform the meta-analysis. The odds ratio (OR) and Mean Difference (MD) were used to analyze the dichotomous data and the continuous data, respectively. For some studies that did not report the mean and standard deviation (SD), we use the method reported by Hozo S.P. et al. [48] to calculate the mean and SD. $\mathrm{I}^{2}$ and $Q$ tests were used to determine statistical heterogeneity. Fixed-effect models were used in the analyses if $P$-values were greater than 0.1 and the $\mathrm{I}^{2}$ was less than $50 \%$. Otherwise, random-effect models were used. In addition, an $\mathrm{I}^{2}$ value of less than $25 \%$ was defined as low heterogeneity, a value between 25 and $50 \%$ was defined as moderate heterogeneity, and a value of $\mathrm{I}^{2}>50 \%$ was defined as high heterogeneity. $P$-values less than 0.05 were considered significant.

\section{CONFLICTS OF INTEREST}

None.

\section{FUNDING}

Supported by Medical Scientific Research Foundation of Guangdong Province, China (A2016228).

\section{REFERENCES}

1. Heald RJ, Ryall RD. Recurrence and survival after total mesorectal excision for rectal cancer. Lancet. 1986; 1:1479-1482.

2. Allaix ME, Giraudo G, Ferrarese A, Arezzo A, Rebecchi F, Morino M. 10-Year Oncologic Outcomes After Laparoscopic or Open Total Mesorectal Excision for Rectal Cancer. World J Surg. 2016; 40:3052-3062.

3. Arezzo A, Passera R, Salvai A, Arolfo S, Allaix ME, Schwarzer G, Morino M. Laparoscopy for rectal cancer is oncologically adequate: a systematic review and metaanalysis of the literature. Surg Endosc. 2015; 29:334-348.

4. Stevenson AR, Solomon MJ, Lumley JW, Hewett P, Clouston AD, Gebski VJ, Davies L, Wilson K, Hague W, Simes J, Investigators AL. Effect of Laparoscopic-Assisted Resection vs Open Resection on Pathological Outcomes in Rectal Cancer: The ALaCaRT Randomized Clinical Trial. JAMA. 2015; 314:1356-1363.

5. Fleshman J, Branda M, Sargent DJ, Boller AM, George V, Abbas M, Peters WR, Jr., Maun D, Chang G, Herline A, 
Fichera A, Mutch M, et al. Effect of Laparoscopic-Assisted Resection vs Open Resection of Stage II or III Rectal Cancer on Pathologic Outcomes: The ACOSOG Z6051 Randomized Clinical Trial. JAMA. 2015; 314:1346-1355.

6. Anthuber M, Fuerst A, Elser F, Berger R, Jauch KW. Outcome of laparoscopic surgery for rectal cancer in 101 patients. Dis Colon Rectum . 2003; 46:1047-1053.

7. Bretagnol F, Lelong B, Laurent C, Moutardier V, Rullier A, Monges G, Delpero JR, Rullier E. The oncological safety of laparoscopic total mesorectal excision with sphincter preservation for rectal carcinoma. Surg Endosc. 2005; 19:892-896.

8. Breukink SO, Pierie JP, Grond AJ, Hoff C, Wiggers T, Meijerink WJ. Laparoscopic versus open total mesorectal excision: a case-control study. Int J Colorectal Dis. 2005; 20:428-433.

9. Zhou ZG, Hu M, Li Y, Lei WZ, Yu YY, Cheng Z, Li L, Shu Y, Wang TC. Laparoscopic versus open total mesorectal excision with anal sphincter preservation for low rectal cancer. Surg Endosc. 2004; 18:1211-1215.

10. Guillou PJ, Quirke P, Thorpe H, Walker J, Jayne DG, Smith AMH, Heath RM, Brown JM. Short-term endpoints of conventional versus laparoscopic-assisted surgery in patients with colorectal cancer (MRC CLASICC trial): multicentre, randomised controlled trial. Lancet. 2005; 365:1718-1726.

11. van der Pas MHGM, Haglind E, Cuesta MA, Fürst A, Lacy AM, Hop WCJ, Bonjer HJ. Laparoscopic versus open surgery for rectal cancer (COLOR II): short-term outcomes of a randomised, phase 3 trial. Lancet Oncol. 2013; 14:210-218.

12. Bonjer HJ, Deijen CL, Abis GA, Cuesta MA, van der Pas MH, de Lange-de Klerk ES, Lacy AM, Bemelman WA, Andersson J, Angenete E, Rosenberg J, Fuerst A, Haglind E, et al. A randomized trial of laparoscopic versus open surgery for rectal cancer. N Engl J Med. 2015; 372:1324-1332.

13. Kang SB, Park JW, Jeong SY, Nam BH, Choi HS, Kim DW, Lim SB, Lee TG, Kim DY, Kim JS, Chang HJ, Lee HS, Kim SY, et al. Open versus laparoscopic surgery for mid or low rectal cancer after neoadjuvant chemoradiotherapy (COREAN trial): short-term outcomes of an open-label randomised controlled trial. Lancet Oncol. 2010; 11:637-645.

14. Jeong SY, Park JW, Nam BH, Kim S, Kang SB, Lim SB, Choi HS, Kim DW, Chang HJ, Kim DY, Jung KH, Kim TY, Kang GH, et al. Open versus laparoscopic surgery for mid-rectal or low-rectal cancer after neoadjuvant chemoradiotherapy (COREAN trial): survival outcomes of an open-label, non-inferiority, randomised controlled trial. Lancet Oncol. 2014; 15:767-774.

15. Gunka I, Dostalik J, Martinek L, Gunkova P, Mazur M, Vavra P. Long-term results of laparoscopic versus open surgery for nonmetastatic colorectal cancer. Acta Chir Belg. 2012; 112:139-147.

16. McKay GD, Morgan MJ, Wong SK, Gatenby AH, Fulham SB, Ahmed KW, Toh JW, Hanna M, Hitos K, South Western Sydney Colorectal Tumor G. Improved short-term outcomes of laparoscopic versus open resection for colon and rectal cancer in an area health service: a multicenter study. Dis Colon Rectum. 2012; 55:42-50.

17. Gouvas N, Tsiaoussis J, Pechlivanides G, Zervakis N, Tzortzinis A, Avgerinos C, Dervenis C, Xynos E. Laparoscopic or open surgery for the cancer of the middle and lower rectum short-term outcomes of a comparative nonrandomised study. Int J Colorectal Dis. 2009; 24:761-769.

18. Pechlivanides G, Gouvas N, Tsiaoussis J, Tzortzinis A, Tzardi M, Moutafidis M, Dervenis C, Xynos E. Lymph node clearance after total mesorectal excision for rectal cancer: laparoscopic versus open approach. Dig Dis. 2007; 25:94-99.

19. Ng SS, Lee JF, Yiu RY, Li JC, Hon SS, Mak TW, Ngo DK, Leung WW, Leung KL. Laparoscopic-assisted versus open total mesorectal excision with anal sphincter preservation for mid and low rectal cancer: a prospective, randomized trial. Surg Endosc. 2014; 28:297-306.

20. Ng SS, Leung KL, Lee JF, Yiu RY, Li JC, Teoh AY, Leung WW. Laparoscopic-assisted versus open abdominoperineal resection for low rectal cancer: a prospective randomized trial. AnnSurg Oncol. 2008; 15:2418-2425.

21. Morino M, Allaix ME, Giraudo G, Corno F, Garrone C. Laparoscopic versus open surgery for extraperitoneal rectal cancer: a prospective comparative study. Surg Endosc. 2005; 19:1460-1467.

22. Feliciotti F, Guerrieri M, Paganini AM, De Sanctis A, Campagnacci R, Perretta S, D'Ambrosio G, Lezoche E. Long-term results of laparoscopic versus open resections for rectal cancer for 124 unselected patients. Surg Endosc. 2003; 17:1530-1535.

23. Jefferies MT, Evans MD, Hilton J, Chandrasekaran TV, Beynon J, Khot U. Oncological outcome after laparoscopic abdominoperineal excision of the rectum. Colorectal Dis. 2012; 14:967-971.

24. Wu WX, Sun YM, Hua YB, Shen LZ. Laparoscopic versus conventional open resection of rectal carcinoma: A clinical comparative study. World J Gastroenterol. 2004; 10:1167-1170.

25. Kellokumpu IH, Kairaluoma MI, Nuorva KP, Kautiainen HJ, Jantunen IT. Short- and long-term outcome following laparoscopic versus open resection for carcinoma of the rectum in the multimodal setting. Dis Colon Rectum. 2012; 55:854-863.

26. Baik SH, Gincherman M, Mutch MG, Birnbaum EH, Fleshman JW. Laparoscopic vs open resection for patients with rectal cancer: comparison of perioperative outcomes and long-term survival. Dis Colon Rectum. 2011; 54:6-14.

27. Cho MS, Kim CW, Baek SJ, Hur H, Min BS, Baik SH, Lee KY, Kim NK. Minimally invasive versus open total mesorectal excision for rectal cancer: Long-term results from a case-matched study of 633 patients. Surgery. 2015; 157:1121-1129.

28. Kim JH, Ahn BK, Park SJ, Park MI, Kim SE, Baek SU, Lee SH, Park SS. Long-term Outcomes of Laparoscopic 
versus Open Surgery for Rectal Cancer: A Single-center Retrospective Analysis. Korean J Gastroenterol. 2015; 65:273-282.

29. Laurent C, Leblanc F, Wutrich P, Scheffler M, Rullier E. Laparoscopic versus open surgery for rectal cancer: longterm oncologic results. Ann Surg. 2009; 250:54-61.

30. Law WL, Lee YM, Choi HK, Seto CL, Ho JW. Laparoscopic and open anterior resection for upper and mid rectal cancer: an evaluation of outcomes. Dis Colon Rectum. 2006; 49:1108-1115.

31. Lelong B, Bege T, Esterni B, Guiramand J, Turrini O, Moutardier V, Magnin V, Monges G, Pernoud N, Blache JL, Giovannini M, Delpero JR. Short-term outcome after laparoscopic or open restorative mesorectal excision for rectal cancer: a comparative cohort study. Dis Colon Rectum. 2007; 50:176-183.

32. Leung KL, Kwok SPY, Lau WY, Meng WCS, Chung CC, Lai PBS, Kwong KH. Laparoscopic-assisted abdominoperineal resection for low rectal adenocarcinoma. Surg Endosc. 2000; 14:67-70.

33. Khaikin M, Bashankaev B, Person B, Cera S, Sands D, Weiss E, Nogueras J, Vernava A, 3rd, Wexner SD. Laparoscopic versus open proctectomy for rectal cancer: patients' outcome and oncologic adequacy. Surg Laparosc Endosc Percutan Tech. 2009; 19:118-122.

34. Braga M, Frasson M, Vignali A, Zuliani W, Capretti G, Di Carlo V. Laparoscopic resection in rectal cancer patients: outcome and cost-benefit analysis. Dis Colon Rectum. 2007; 50:464-471.

35. Gonzalez QH, Rodriguez-Zentner HA, Moreno-Berber JM, Vergara-Fernandez O, Tapia-Cid de Leon H, Jonguitud LA, Ramos R, Moreno-Lopez JA. Laparoscopic versus open total mesorectal excision: a nonrandomized comparative prospective trial in a tertiary center in Mexico City. Am Surg. 2009; 75:33-38.

36. Veenhof AA, Engel AF, Craanen ME, Meijer S, de Langede Klerk ES, van der Peet DL, Meijerink WJ, Cuesta MA. Laparoscopic versus open total mesorectal excision: a comparative study on short-term outcomes. A singleinstitution experience regarding anterior resections and abdominoperineal resections. Dig Surg. 2007; 24:367-374.

37. Seshadri RA, Srinivasan A, Tapkire R, Swaminathan R. Laparoscopic versus open surgery for rectal cancer after neoadjuvant chemoradiation: a matched case-control study of short-term outcomes. Surg Endosc. 2012; 26:154-161.

38. Gong J, Shi DB, Li XX, Cai SJ, Guan ZQ, Xu Y. Shortterm outcomes of laparoscopic total mesorectal excision compared to open surgery. World J Gastroenterol. 2012; 18:7308-7313.
39. Liang X, Hou S, Liu H, Li Y, Jiang B, Bai W, Li G, Wang W, Feng Y, Guo J. Effectiveness and safety of laparoscopic resection versus open surgery in patients with rectal cancer: a randomized, controlled trial from China. J Laparoendosc Adv Surg Tech A. 2011; 21:381-385.

40. Lujan J, Valero G, Biondo S, Espin E, Parrilla P, Ortiz H. Laparoscopic versus open surgery for rectal cancer: results of a prospective multicentre analysis of 4,970 patients. Surg Endosc. 2013; 27:295-302.

41. Lujan J, Valero G, Hernandez Q, Sanchez A, Frutos MD, Parrilla P. Randomized clinical trial comparing laparoscopic and open surgery in patients with rectal cancer. Br J Surg. 2009; 96:982-989.

42. Jayne DG, Guillou PJ, Thorpe H, Quirke P, Copeland J, Smith AM, Heath RM, Brown JM, Group UMCT. Randomized trial of laparoscopic-assisted resection of colorectal carcinoma: 3-year results of the UK MRC CLASICC Trial Group. J Clin Oncol. 2007; 25:3061-3068.

43. Koulas SG, Pappas-Gogos G, Spirou S, Roustanis E, Tsimogiannis KE, Tsirves G, Tsimoyiannis EC. Evaluations of laparoscopic proctocolectomy versus traditional technique in patients with rectal cancer. JSLS. 2009; 13:564-573.

44. Strohlein MA, Grutzner KU, Jauch KW, Heiss MM. Comparison of laparoscopic vs. open access surgery in patients with rectal cancer: a prospective analysis. Dis Colon Rectum. 2008; 51:385-391.

45. Leung KL, Kwok SPY, Lam SCW, Lee JFY, Yiu RYC, Ng SSM, Lai PBS, Lau WY. Laparoscopic resection of rectosigmoid carcinoma: prospective randomised trial. Lancet. 2004; 363:1187-1192.

46. Jeong SY, Park JW, Nam BH, Kim S, Kang SB, Lim SB, Choi HS, Kim DW, Chang HJ, Kim DY, Jung KH, Kim TY, Kang GH, et al. Open versus laparoscopic surgery for mid-rectal or low-rectal cancer after neoadjuvant chemoradiotherapy (COREAN trial): survival outcomes of an open-label, non-inferiority, randomised controlled trial. Lancet Oncol. 2014; 15:767-774.

47. Songun I, Putter H, Kranenbarg EM, Sasako M, van de Velde CJ. Surgical treatment of gastric cancer: 15-year follow-up results of the randomised nationwide Dutch D1D2 trial. Lancet Oncol. 2010; 11:439-449.

48. Hozo SP, Djulbegovic B, Hozo I. Estimating the mean and variance from the median, range, and the size of a sample. BMC Med Res Methodol. 2005; 5:13. 